\title{
Korean and Japanese Chaoben
}

In the period 1850-1950 covered by this book, China had a vibrant chaoben culture that extended into almost every facet of life for the common people. By contrast, chaoben culture in Korea and Japan was much more limited. I draw this conclusion from my investigations of the markets for handwritten books and booklets in Korea and Japan and from the types of handwritten materials available in antiques stores and flea markets there.

In premodern times, people in both Korea and Japan usually wrote with a brush and black ink on handmade paper. They also wrote in classical Chinese [wenyanwen 文言文], generally omitting punctuation marks. In Korea, following Chinese practice, the name of the copyist, the date of the copy, or its location were usually omitted. It is often possible to find clues in the text to give some likely answers to these questions. In the "official" or "semiofficial" handwritten materials I have gathered, such as tax records (not discussed in this study) or the Japanese chaoben discussed below, names, dates, and locations are regularly given, although this is not the case for items of an unofficial nature.

Among the chaoben produced in Korea that I have seen, almost every category of subject represented in the Chinese handwritten materials was also produced in Korea: copying of Buddhist or Daoist religious texts, genealogies, fortunetelling texts, examples of letters and social announcements, herbal medical recipes, etc. The differences compared to material from China that I perceive were that people in Korea who could write in Chinese with good calligraphy were in general from the educated and elite classes, not from the lower economic or social strata. Therefore, their interests focused on propagating and endorsing the highly respected Confucian ritual behavior prescribed for all critical life transitions - of which funerals and weddings were the most important. Korean elites made great efforts to learn the numerous details and procedures for ceremonies such as those relating to funerals, and as a result they produced lengthy and detailed descriptions of all aspects of funerals, and they kept records of the money offerings made by guests at funerals and of the eulogies delivered at the funeral or later at the gravesite during a memorial service. I have found many such handwritten materials in Korea, but they are much less common in China.

Korean scholars preferred to follow the Chinese practice of writing in the standard [zhengkai 正楷] style of calligraphy. Chinese friends have sometimes told me the classical Chinese texts of the Korean writers were "strange" or "incorrect" compared to the classical Chinese they had learned in school. The penchant for paying great honor to Confucian rituals and theirmany requirements is also reflected in the woodblock prints from the Choson period of the 1800 s to 1910 available in the marketplace. The Koreans reprinted/republished

(C) RONALD SULESKI, 2018 | DOI:10.1163/9789004361034_015

This is an open access chapter distributed under the terms of the prevailing CC-BY-NC License at the time of publication. 
many classical Chinese texts concerning ritual behavior. They also did this for mid- to late Qing compendiums that could be useful for the elites or for government officials or for schoolteachers. The titles of some Choson-era woodblock prints I have collected illustrate these areas of elite interest: Standard Literary Styles [Samun ryujung 사문류중/事 文類眾], a compendium of general knowledge on official and government affairs; Popular Knowledge, Volume 3 [Tonggam, wonji sam 통감 권지삼/通鑑卷之三], a history of the Chinese Eastern Han Dynasty (194-128BCE), dated 189o. It is 12 inches $(30.48 \mathrm{~cm}) \mathrm{h}$ $\times 81 / 4$ inches $(20.95 \mathrm{~cm})$ w, and was purchased in Seoul in January 2011. An example of a text produced in Korea and aimed at the same higher strata of Koreans, is Exchanging Conventional Greetings [Hanwon ch'arok 한훤차록/寒暄简錄], a guide about how to properly address government documents, letters, and official reports. The text was compiled in 1606, but this reprint appears to be latter Yi Choson 이조선/李朝鮮 (i.e., 180os). It is $103 / 4$ inches $(27.3 \mathrm{~cm}) h \times 7^{1 / 2}$ inches $(19.05 \mathrm{~cm})$ w, and was purchased in Seoul in December 2010.

The handmade paper used in Korean and Japanese chaoben tended to be of a better quality than that used for typical Chinese chaoben. The Korean and Japanese paper regularly had fewer impurities. It was whiter than that used in most Chinese examples. It was heavier, meaning the paper was slightly thicker or more durable; mulberry bark was the favored ingredient in much Korean handmade paper. But like most handmade paper, it was more like light cloth than is true of machine-made paper in common use today. Both the Koreans and the Japanese occasionally used twine or twisted paper to bind the pages, and leaves were larger sheets of paper folded in half, with the folded edge being the "outer" edge of the page while the loose edges were the ones bound together along the right edge of the book.

The most noticeable difference between Chinese and Korean chaoben and those from Japan is that the Japanese preferred to write using running-hand script [xingcaoshu 行 草書/gyōsho 行書] style. This made the text flow nicely, especially when Chinese characters [kanji 漢字] were mixed with the Japanese phonetic kana 仮名かな script. This practice was (and still is) regularly seen in diaries and poetry. I had great difficulty in reading Japanese handwritten texts, though many educated Japanese can read these texts. Japanese official documents, often largely or entirely using characters, are less difficult to read.

Japanese handwritten materials appear to have rapidly fallen out of use by most people beginning in the twentieth century, just as did the printing of woodblock books. Along with other Western practices eagerly adopted in the Meiji 明治 period (1868-1912), commercial printing machines for lithography and typography came into common use.

Below are a few examples of chaoben I have collected from Korea and Japan. These examples are also listed in Appendix A in order to make Appendix a a complete listing of the chaoben mentioned in this book. 


\section{Korean Chaoben}

Eulogies [Mansa 만사/輓詞]. The front and back covers are missing from this fifty-fivepage handwritten manuscript bound with twine. It is a lengthy and detailed commentary on the proper way to hold a funeral and burial. Pages 1 to 44 invoke the words of Confucius, "the Master said" [chawal 자왈/子曰] to outline every step in the correct ritual process. A diversion from this explanation (pp. 44-53) discusses the ritual for weddings [hollye 혼례/婚禮], and the final extant text then returns to the topic of honoring the deceased.

The handwritten text includes two funeral orations [chaemun 제문/祭文], which appear to be eulogies written by the author of the text or by a relative and then copied into this text. They have information that is useful for placing the entire manuscript in the context of its location and the family described. The family home was in Yangju 양주/陽州, a place originally located in the Chosŏn 조선/朝鮮 period east of Seoul [Hanyang 한양/漢陽] near the Great East Gate [Tongdaemun 동대문/東大門] of the city. The place name was later transferred further eastward and today is located between the cities of Ǔijŏngbu 의정부/議政部 and Tongduch’ŏn 동두천/東豆川 [originally written Tongduch’ŏn 동두천/東頭川]. One of the families involved in this text was surnamed Hŏ 허/許. The first eulogy was written for the writer's maternal grandfather, whose name was Hŏ Kasŏn 허가선/許嘉善. The family house in the grandfather's time was located in Meiho 매호/梅湖. The name Sanp'ungsŏng 산붕성/山朋城 also appears in this eulogy.

In the second eulogy, on pp. 53-54, the deceased is a female relative, the wife of an official named Kang 강/姜 from Posan 보산/普山, whose name is given as Madame Pak from Miryang 밀양/密陽 [Posan Kang sukpuin, Miryang Pak ssi 보산강숙부인, 밀양 박씨/普山姜淑夫人, 密陽朴氏]. The polite phrase sukpuin 숙부인/淑夫人 was used in traditional Korea to refer to the wife of an official. We find in the first eulogy on pp. 26-27 that several members of the family achieved the status of saengworn 생원/生 員, the equivalent of the Chinese status of xiucai 秀才. They had the surnames Chŏng 정/鄭 and Sŏ 서/徐. This information reinforces my interpretation that the people who could read and write classical Chinese in Chosen Korea came from the educated higher classes. The dates given in the text [ŭlsa year 을사년/乙巳年 and pyŏng'o year 병 오년/丙午年] were 1845 and 1906. Judging by the use of red-orange circles and lines used in the text to indicate critical portions, as in other chaoben from Korea in my collection, and the quality of the paper, dating it around 1906 is reasonable. The book is $93 / 4$ inches $(24.76 \mathrm{~cm}) \mathrm{h} \times 9^{-7} / 8$ inches $(25.02 \mathrm{~cm})$ w, making it almost square, which was uncommon in Chinese chaoben. I bought it at the Sŭngmun'gak 승문각/承文閣 in Insadong 인사동/仁寺洞, Seoul, in December 2010.

Items for Mourning [Ch'osang ch'egu 초상제구/初喪諸具]. This 76-page chaoben is devoted mostly to funeral and mourning rituals, and it cites the Chinese Confucian 
scholar Zhu Xi (1130-120o), who helped to codify these rules. Such sentences begin with the phrase "Master Zhu said" [Chuja wal 주자왈/朱子曰].

On page 57, the book cites the National Code [Kyŏngguk taejŏn 경국대전/經國大典], a comprehensive collection of laws and explanations of the administrative structure of the government issued in 1485 . The text uses this as a basis for a discussion of government and how to govern the country. On pp. 57-61, the book details Korean factional politics from ${ }^{1676}$ to 1718 . The section "Discussing the Parties of the East and West" [Tong-sŏ myŏngdang non 동서명 당론/東西明黨論] describes the chief government officials and the faction leaders. The entire late Choson period was a time of intense factionalism and party/clan rivalry among the Yangban 양반/兩班 elites. They fought among themselves, assassinated or exiled rivals, and self-righteously proclaimed their own sincerity. These constant changes in power are outlined on pp. 61-67. On page 67, the author includes a chart of all the Yi Choson kings, ending with the "current" [kŭmsang 금상/今上] King Ch’ŏljong [Ch’ŏljong wang 철종왕/哲宗王; r. 1849-1863]. Because he is indicated as the current king, we know that this text was written prior to 1863 .

Included with this chaoben is a promissory note dated 1872 [imja nyŏn 임자년/王子 年]. The note concerns Yang Hongjin 양홍진/梁洪鎮, who borrowed money from Kim Ch'unsŏng 김춘성/金春成 to conduct a funeral. It is possible that he borrowed this book for use in the rituals. It is also likely that he put this note inside the book as he was referring to it at the time of organizing a funeral. Also inserted was the corner of an envelope with the name Yi Sanggyu 이상규/李常圭 with his seal. It is unclear whether this was the author or owner of the book-or whether this was a type of "subversive" text that would have been dangerous if found by certain factional leaders and therefore hid its observations on political party factionalism within a book about funeral arrangements. The book is $7^{3 / 4}$ inches $(19.68 \mathrm{~cm}) \mathrm{h} \times 5^{1 / 4}$ inches $(13.34 \mathrm{~cm}) \mathrm{w}$. I bought it in Seoul in September 2005.

One Thousand Three Hundred Words [Ch'on sambaekcha 천삼백자/千三百字]. Neatly written on handmade rice paper, this fifty-eight-page manuscript appears at first glance to be a typical Chinese vocabulary list. The four-word rhymes actually total 1,160 words. The target audience is young students, perhaps ages ten to fourteen. The text begins with all the basics of the Chinese worldview: "Father, mother, siblings; male, female, elder, young, gentleman, lady, wonderful blessings; virtuous wife, filial offspring" [ Pumo hyŏngje, namnyŏ noso; pubu haengbok, hyŏnch'o hyoson 부모형제, 남녀노소; 부부행복, 현 처효손/父母兄弟, 男女老少 ; 夫婦幸福, 賢妻孝孫; p. 1]. This text was in fact used by a schoolchild, as can be seen from markings made with a pencil or pen on certain pages. Purchased in Seoul, it was bound with light cord in the five-ring Korean style. Further on in the text, it is clear the text was written for Korean schoolchildren. For example, “Tan'gun descended, and organized his royal court” [Tan'gun kangnim, chŏngsin tan'gyŏl 단군강림, 정신단결/檀君降臨, 廷臣團結; pp. 10-11]; “The great Korean valiant fighters, 
protect the fatherland" [TaeHan kŏna, choguk suho 대한건아, 조국수호/大韓健兒, 祖國 守護; p. 11]. Tan'gun [Tan'gun wanggŏm 단군왕검/檀君王儉] is considered the legendary founder of Korea.

The more difficult questions to answer were: When was this text written? In what context was the text prepared? The text gives various clues. "Uphold the constitution, the central government, democracy and independence" [Hŏnb̆ор ŭiğo, chungang chŏngbu, minju tongnip 헌법의거, 중앙정부, 민주독립/憲法依據, 中央政府, 民主獨 立; pp. 11 and 12]. "Wash your hands, be cool and composed; advance hygiene, protect everyone with inoculations" [Sesu chinjŏng; chinbo wisaeng, yebang chusa 세수진정; 진 보위생, 예방주사/洗手鎮靜 ; 進步衛生, 預防注射; p. 36]; “Bring the episode to an end; peace is announced” [Cheap chongmak, chŏngjŏn sŏnŏn 제압 종막, 정전선언/制壓終幕, 停戰宣言; pp. 55 and 56]. The cover is made of heavy brown paper, of the type often used for bags of rice, and seems to have been cut and sewn by machine; on the cover the date written is "twelfth month of the pyŏng'o year" [Pyŏng'o nyŏn sibiwŏl 병오년 십 이월/丙午年拾貮月]. The pyŏng'o year fell in 1906 and 1966. In 19o6, as far as I can tell, Koreans did not use the terms central government or constitution, but at that time the Japanese did. In 1966, Koreans used all the terms here and had suffered upheavals at the end of World War II in 1945 and the Korean War in the early 195os, so the contents of the text would fit the historical circumstances of those times. But textbooks used in 1966 were rarely of the rice-paper, Chinese-style type displayed in this document.

My conclusion, however, is that the book was written in 1966. The phrase "ceasefire" [chŏngjin sŏnŏn 정전선언/停戰宣言] was in common usage in South Korea after the Korean War. Moreover, assuming this was used in the 196os, perhaps by a village schoolteacher to instruct his students in learning Chinese characters, which were commonly used at that time, then this document shows the extension of the Korean chaoben tradition well into modern times. The book is 8 inches $(20.32 \mathrm{~cm}) \mathrm{h} \times 7$ inches $(17.78 \mathrm{~cm}) \mathrm{w}$ and was bought in Seoul in January 2011.

Criminal Inquest [Sarok choeinjang 살옥죄인장/殺獄罪人狀]. This handwritten document from Korea is discussed in Appendix в and is included in the complete chaoben list in Appendix A.

\section{Japanese Chaoben}

Records Prepared in 1811 [Bunka hachinen fuyu okakitsuki 文化八年冬御書附]. The subtitle on the front is "Records Handed to the Official at the Time of His Transfer" [Odaikan kōtai no toki no hōsesōrōbun 御代官交代之時之報請候分]. This handwritten collection of documents was prepared for the officer in charge of the shogun's lands [bugyo 奉行] at the time the officer was being transferred from the rural estate to the 
capital at Edo. This collection would then be given to the new officer in charge, who would proceed to the estate.

The fifty-three pages contain records from 1657 to 1811 . Pages 1-12 contain a list of documents, possibly placed in a case, that were being turned over; they were prepared by Tate of Awa [堅安房; it is unclear how to read this inscription], probably an official. The record on pp. 17-26 is 1783 and was “copied by brush" [mōgaiki 毛外記]. The record on pp. 41-47, undated but probably from 1811, seems to be an account of the general state of affairs. It makes reference to girls gathered to perform jōruri 净瑠璃, narrative music that is accompanied by the shamisen 三味線, on p. 45. I was unable to read the running-hand script preferred by the Japanese and used on these pages. On pp. 48-49, we see that these documents were copied by Watanabe Seihei 渡邊瀨兵衛, who was the shogunal administrator of Osaka (then written as Ósaka machi 大坂町). His seal in black is on this collection. On the back cover, p. 54, is the phrase "A total of thirty sheets have been put together here" [uwagami tomo sanjūmai 上紙共三拾枚]. The book is $9^{3 / 4}$ inches $(24.76 \mathrm{~cm}) \mathrm{h} \times 63 / 4$ inches $(17.15 \mathrm{~cm})$. I bought it in Tokyo in August 2007.

Land Documents [Densho meitsuki shōmon Mukai 田所名附證文向]. These are handwritten records that describe the sale, transfer, and disposition of land. The sale of government-owned land is recorded on pp. 24-26. Records concerning who will be responsible for managing and working the land among family members are on pp. 3043. This eighty-page collection contains nine records, each of which indicates the names of the individuals involved. The lands referred to in this collection were in Echigo 越後, an area lying on the central [chūbu 中部] and western side of the main Japanese island of Honshū 本州, roughly equivalent to the present-day prefecture of Niigata 新潟. The region has mountainous areas, flat land for agriculture, and shoreline onto the Sea of Japan.

The specific address, as written on p. 79, was Echigo, Koshi-gun, Takanami-hiro 越 後古志郡高浪(広?). The official responsible for this location was Hayashi Kyūe 林久恵, who was the headman in charge of the Urase Extended Village. This is written in the record as “Kagumi Urase-mura jūnin Hayashi Kyūe shū 加組浦瀨村住人林久恵主.” [In 1889 this village was incorporated with other villages and renamed Yamamoto Village 山本村, and in 1954 is was made a part of Nagaoka City 長岡市, an area that covers much of central Niigata Prefecture. The city boundaries stretch from the mountains to the seashore.] The records were written by a retainer [omi 臣] to the lord of the area. The omi was named Senji 仙児. His seal appears below his name on p. 79, which lists him by his correct title as "retainer" [shinsh $i$ 臣子]. This collection was prepared in 1849. The book is $10^{3 / 4}$ inches $(27.31 \mathrm{~cm}) \mathrm{h} \times 9^{3 / 4}$ inches $(24.76 \mathrm{~cm}) \mathrm{w}$. I bought it in Tokyo in 1995 . 